\title{
PEMANFAATAN NEW MEDIA DALAM PROMOSI PERHOTELAN DI KOTA BENGKULU
}

\author{
Kukuh Bagus Suryo Waskito ${ }^{1}$, Eceh Trisna Ayuh ${ }^{2}$ \\ Universitas Muhammadiyah Bengkulu ${ }^{1,2}$ \\ kukuhbagus08@gmail.com ${ }^{1}$
}

\begin{abstract}
ABSTRAK
Tujuan penelitian ini adalah berfokus tentang bagaimana media baru dijadikan sebagai sarana promosi bagi pihak perhotelan yang ada di kota Bengkulu. Metode penelitian ini menggunakan metode kualitatif dan model teori Difusi Inovasi. Hasil penelitian ini yaitu bahwa kajian 4 unsur teori Difusi Inovasi (inovasi, jangka waktu, saluran komunikasi dan sosial) memiliki hubungan dengan adanya pemanfaatan media baru saat ini. Simpulan, Seperti adanya pemilihan inovasi yang memiliki dampak di era sekarang, jangka waktu yang dipilih untuk memutuskan kenapa harus mempromosikan melalui media baru, saluran komunikasi yang memiliki pengaruh tersendiri seperti jangkaun yang luas dalam promosi, hingga sosial yang membuat adanya perubahan hingga timbulnya pemanfaatan media baru sebagai promosi dari pihak hotel yang ada di kota Bengkulu.
\end{abstract}

Kata Kunci: Media Promosi, New Media, Promosi

\section{ABSTRACT}

The purpose of this study is to focus on how the new media is used as a promotional tool for hotels in the city of Bengkulu. This research method uses qualitative methods and Innovation Diffusion theory models. The results of this study are that the study of 4 elements of the theory of innovation diffusion (innovation, time period, communication and social channels) has a relationship with the use of new media at this time. Conclusion, Like the selection of innovations that have an impact in the current era, the time period chosen to decide why should promote through new media, communication channels that have their own influences such as a wide range of promotions, to social that makes changes to the emergence of the use of new media as a promotion from the hotel in the city of Bengkulu.

Keywords: Promotion Media, New Media, Promotion

\section{PENDAHULUAN}

Perkembangan bisnis di era globalisasi atau era digital saat ini digambarkan dalam dua kata, yaitu tepat serta cepat. Hanya dengan menggunakan alat bantu yang dinamakan gadget, maka siapa pun bisa membuka informasi dan mencari hal apapun yang ada di internet dengan mudah. Seiring berkembangnya zaman, berbagai hal seperti barang dan jasa yang bisa didapatkan dengan mudah melalui jejaring internet. Hal ini menjadikan keunggulan tersendiri didalamnya, jika melihat ke arah belakang, dahulu betapa sulitnya untuk mendapatkan produk yang diinginkan. 
Perkembangan bisnis di era digital saat ini juga menunjukkan adanya potensi bahwa orang bisa mendapatkan hampir semua produk yang diinginkan dengan mudah, mulai dari hal yang simpel seperti peralatan rumah tangga dan lainnya.

Perkembangan bisnis di era digital dengan menggunakan media sosial sebagai media informasi mampu memberikan lebih banyak keuntungan. Dalam hal ini, bisa memanfaatkan sosial media seperti Facebook, Twitter, Instagram dan lainnya untuk melakukan aktifitas bisnis yang dilakukan. Bahkan juga tak hanya merambah di bisnis saja, tapi juga sector lainnya.

Dalam bisnis diperlukan adanya strategi untuk bisa mempertahankan produk atau konsumen agar bisa bertahan di dalam pasar, ditambah dengan era sekarang yang memasuki era persaingan yang sudah semakin ketat dan banyaknya kompetitor bisnis lainnya yang sudah memutar otak dan strategi, maka persaingan bisnis dari produk apapun akan semakin kompetitif.

Persaingan dalam dunia bisnis memang sedari dulu selalu menarik untuk dikaji, terlebih lagi sekarang sudah banyak para kompetitor bisnis yang secara eksplisit mempromosikan, mengenalkan bisnis mereka secara langsung. Khususnya di Indonesia, terdapat berbagai daerah yang menjadi pusat destinasi wisata, tentunya memerlukan suatu nilai tambah dalam menunjang wisata daerah tersebut, salah satunya penginapan (hotel) yang perlu diperhatikan, karena wisata tentunya berhubungan dengan penginapan.

Perhotelan sangat memerlukan strategi untuk bisa menarik minat dari pengunjungnya, karena penilaian dan pencapaian dari sebuah hotel dilihat dari bagaimana jumlah pengunjung dan bagaimana rating hotel tersebut. Karena penilaian tersebutlah yang mampu menentukan dinamika pergerakan bisnis hotel tersebut.

Hotel adalah suatu jenis akomodasi yang mempergunakan sebagian/seluruh bangunan untuk menyediakan jasa pelayanan penginapan, makan dan minum yang dikelola secara komersial serta memenuhi ketentuan persyaratan yang ditetapkan pemerintah (Bataafi, 2005).

Khususnya di Bengkulu sendiri, persaingan antar hotel terbilang cukup kompetitif dalam menarik perhatian pengunjungnya, karena itulah pentingnya strategi dalam bisa melakukan hal tersebut.

Maka tidak heran para pelaku bisnis perhotelan di kota Bengkulu saat ini menggunakan alat bantu untuk sebagai sarana promosi hotel-hotel tersebut. Salah satunya dengan menggunakan new media (media baru) yang saat ini sudah sangat akrab dalam masyarakat.

Media baru disebut juga new media digital adalah media yang kontennya berbentuk gabungan data, teks, suara, dan berbagai jeni gambar yang disimpan dalam format digital dan disebarluaskan melalui jaringan berbasis kabel optic broadband, satelit dan sistem gelombang mikro (Flew, 2008). Dengan kata lain, bahwa media baru ini merupakan generasi penyempurna dari media-media konvensional sebelumnya (cetak dan elektronik) dengan kelebihan dan kekuatan yang tidak dimiliki oleh mediamedia konvensional. 
Secara sederhananya, media baru ini memiliki nilai unggul yaitu dengan memiliki fasilitas yang sesuai dengan perkembangan zaman saat ini,yaitu cepat, praktis dan mudah diakses melalui alat bantu gadget yang saat ini hampir masyarakat modern saat ini memiliki gadget. Media baru dapat dimanfaatkan dalam berbagai sisi, bisa dari sisi mudahnya akses untuk mendapatkan informasi, berkomunikasi dengan kerabat yang jauh, menjangkau bahan edukasi dari berbagai jenis sumber hingga digunakan sebagai alat bantu untuk memulai bisnis di era sekarang ini.

Melihat dari keunggulan yang dimiliki oleh media baru ini, maka menjadikan jalan bagi pelaku bisnis di bidang perhotelan untuk bisa menjangkau massa dan sebagai promosi hotel-hotel tersebut dengan cara yang mudah dan jangkauannya luas.

Seperti yang terjadi di Bengkulu, para pelaku bisnis di bidang perhotelan melakukan pemanfaatan penggunaan media baru ini sebagai alat bagi promosi hotelhotel, dikarenakan dengan jangkauan yang luas sehingga bisa menjadi jalan yang tepat untuk sebagai media promos dalam bisnis perhotelan.

\section{METODE PENELITIAN}

Metode penelitian yang akan digunakan adalah penelitian kualitatif yaitu jenis upaya untuk mencari pemecahan masalah dengan menggambarkan peristiwa-peristiwa berdasarkan fakta atau data-data yang ada di lapangan.(Moleong, 2006).

Dalam metode kualitatif, realitas dipandang sebagai sesuatu yang berdimensi banyak, sesuatu kesatuan yang utuh, serta berubah-ubah. Sehingga biasanya, rancangan penelitian tersebut tidak disusun secara rinci dan pasti sebelum penelitiannya dimulai. Untuk alasan itu pula, pengertian kualitatif sering diasosiasikan dengan teknik analisis data dan penulisan kajian penelitian.

Pada penelitian ini akan menggunakan berbagai sumber data sebagai sumber informasi yang akurat seperti halnya dokumentasi dan menggunakan metode wawancara di dalamnya namun sebelumnya akan dilakukan tahapan observasi untuk melihat beberapa subjek penelitian yang terkait dengan permasalahn yang akan diangkat. Pada subjek penelitian ini melibatkan beberapa hotel yang ada di kota Bengkulu, seperti hotel A,B,C dan D.

Penelitian ini nantinya akan menggunakan informan, informan dibutuhkan agar penelitian ini bisa berjalan dengan sesuai peneliti serta mendapatkan data-data yang akurat serta informasi tambahan lainnya yang bisa menjadi bahan bagi penelitian ini. Dalam pengambilan informan dalam penelitian ini maka akan digunakan teknik Purposive Sampling.

Penelitian ini nantinya akan turut melibatkan pula orang-orang yang terkait dengan perhotelan yang ada di Bengkulu, seperti pihak manajer atau bagian public relation (PR), untuk bisa memberikan data-data dan informasi yang akurat serta sesuai dengan penelitian ini. Serta dalam penelitian ini nantinya akan menggunakan teknik analisis data yang digunakan sebagai alat oleh peneliti untuk menganalisa berbagai informasi yang didapatkan sehingga nantinya tidak akan terdapat kesalahan, dalam menganalisis data ini peneliti juga menggunakan filterasi dalam informasi yang 
didapatkan dari informan, yaitu jika informasi yang didapatkan memiliki bobot yang tidak mencapai validasi, maka peneliti akan menganalisa terlebih dalam lagi.

\section{HASIL PENELITIAN}

Berdasarkan pengamatan dan wawancara mendalam tentang pemanfaatan new media dalam promosi perhotelan di kota Bengkulu yang dikaji melalui 4 unsur dalam asumsi model Difusi Inovasi (Inovasi, Jangka Waktu, Saluran Komunikasi dan Sosial).

\section{Pemanfaatan New Media Dari Model Difusi Inovasi: Inovasi}

Inovasi adalah gagasan, tindakan atau barang yang dianggap baru oleh seseorang, inovasi menjadi suatu langkah baru yang diambil demi menciptakan suasana hingga dampak yang belum bisa ditimbulkan sebelumnya. Dalam kasus permasalahan penelitian ini, inovasi disini yaitu adalah adanya media baru yang hadir dalam industri perhotelan dan memiliki dampak atau pengaruh yang besar dalam pengembangan bisnis perhotelan tersebut

Faktor yang dapat mempengaruhinya yaitu dengan adanya perkembangan zaman saat ini sehingga dengan adanya inovasi dari media baru ini, dapat hadir dalam dunia bisnis perhotelan yang ada di kota Bengkulu terkhususnya.

\section{Pemanfaatan New Media Dari Model Difusi Inovasi: Jangka Waktu}

Jangka waktu, yakni proses keputusan inovasi dari mulai seseorang mengetahui sampai memutuskan untuk menerima atau menolaknya. Pengukuhan terhadap keputusan itu sangat berkaitan dengan dimensi waktu. Para pelaku bisnis perhotelan yang ada di kota Bengkulu tidak serta merta langsung 'nyaman' dalam memilih media baru sebagai media partner bagi mereka (pihak hotel-hotel di kota Bengkulu). Perlu adanya masa transisi yang harus dilakukan dalam menyesuaikan dan menggunakan media baru tersebut.

\section{Pemanfaatan New Media Dari Model Difusi Inovasi: Saluran Komunikasi}

Saluran komunikasi, adalah alat untuk menyampaikan pesan-pesan inovasi dari sumber kepada penerima. Pada penelitian yang dikaji ini, berdasarkan asumsi dari Difusi Inovasi, secara sederhananya adalah saluran komunikasi dihubungkan dengan adanya media sebagai 'jembatan' bagi para pelaku yang menggunakan media baru dan sasaran/target yang menjadi fokus dari pelaku ini.

Pemanfaatan new media untuk sarana promosi bagi perhotelan yang ada di kota Bengkulu ini, menggunakan media komunikasi jenis massa sangatlah diuntungkan, karena faktor utamanya adalah bisa menjangkau sasaran yang luas sehingga diinginkan dari para pelaku bisnis hotel-hotel yang ada di kota Bengkulu.

\section{Pemanfaatan New Media Dari Model Difusi Inovasi: Sosial}

Sistem sosial merupakan sistem yang diterapkan oleh kumpulan unit yang ada di lingkungan tersebut, menerapkan sistem atau aturan yang berlaku dan berkembang di perubahan zaman demi menunjang lingkungan tersebut. 
Sosial merupakan faktor penting dalam adanya inovasi, karena sosial yang menggerakan adanya perubahan yang bisa dirasakan saat ini. Sosial pun bisa berubah karena pola pikir yang sudah maju dan berpengetahuan, adanya kebutuhan dan kemauan yang berkembang dan berubah sehingga mempengaruhi orang lain untuk mengikuti perubahan yang terjadi.

\section{PEMBAHASAN}

\section{Pemanfaatan New Media Dari Model Difusi Inovasi: Inovasi}

Inovasi adalah gagasan, tindakan atau barang yang dianggap baru oleh seseorang, inovasi menjadi suatu langkah baru yang diambil demi menciptakan suasana hingga dampak yang belum bisa ditimbulkan sebelumnya. Dalam kasus permasalahan penelitian ini, inovasi disini yaitu adalah adanya media baru yang hadir dalam industri perhotelan dan memiliki dampak atau pengaruh yang besar dalam pengembangan bisnis perhotelan tersebut (Mulyana, 2005).

Inovasi dalam konteks pemanfaatan new mediapada perhotelan di kota Bengkulu yaitu dengan adanya menggunakan media-media yang berbasis online sebagai strategi yang dilakukan dalam melakukan sarana promosi hotel-hotel tersebut. Sebut saja media baru yang terlibat di dalamnya yaitu seperti OYO, RedDoorz, Airy dan masih banyak lagi media partner dalam bisnis perhotelan yang ada di kota Bengkulu. Pemilihan media partner yang disebutkan diatas memiliki faktornya tersendiri, bukan semata-mata karena sebagai media kerja sama, melainkan adanya :

1. Menggunakan media baru sebagai partner karena jangkauan yang lebih luas (nasional dan internasional)

2. Dengan adanya media partner seperti OYO, RedDoorz dan Airy membuat hotel-hotel tersebut tidak hanya di promosikan, namun mendapatkan fasilitas dari kerja sama yang menjadikan keuntungan dari pihak hotel-hotel yang bersangkutan

3. Mengikuti zaman, karena dengan bergabung dan memanfaatkan inovasi ini (new media), perhotelan di kota Bengkulu bisa mengikuti perkembangan dan dinamika bisnis perhotelan yang ada di Indonesia dan terkhususnya di kota Bengkulu.

\section{Pemanfaatan New Media Dari Model Difusi Inovasi: Jangka Waktu}

Jangka waktu, yakni proses keputusan inovasi dari mulai seseorang mengetahui sampai memutuskan untuk menerima atau menolaknya. Pengukuhan terhadap keputusan itu sangat berkaitan dengan dimensi waktu. Para pelaku bisnis perhotelan yang ada di kota Bengkulu tidak serta merta langsung 'nyaman' dalam memilih media baru sebagai media partner bagi mereka (pihak hotel-hotel di kota Bengkulu). Perlu adanya masa transisi yang harus dilakukan dalam menyesuaikan dan menggunakan media baru tersebut (Suprapto, 2006).

Dalam unsur jangka waktu model Difusi Inovasi ini, diperlukan faktor-faktor yang menjadi alasan bagi perhotelan di kota Bengkulu dalam menggunakan jasa media partner sebagai ajang promosi, adapun yaitu : 
1. Transisi Waktu, penggunaan atau pemanfaatan media baru sebagai media promosi bukan keputusan yang memiliki jangka waktu singkat, perlu adanya penyesuaian dan faktor penting lainnya seperti pengaruh zaman dan kebutuhan dari masyarakat (konsumen) yang sudah mengalami perkembangan didalamnya

2. Era Digital, perkembangan zaman memiliki pengaruh yang besar sebagai alasan dari para perhotelan di kota Bengkulu dalam berkerja sama dengan pihak seperti OYO, RedDoorz dan Airy. Melihat karena adanya perkembangan zaman, maka menjadikan para pelaku bisnis ini harus memilih strategi yang tepat dalam bertransaksi atau mempromosikan bisnis mereka, sehingga perhotelan yang ada di kota Bengkulu ini bisa memiliki 'amunisi' dalam persaingan dengan bisnis lainnya.

\section{Pemanfaatan New Media Dari Model Difusi Inovasi: Saluran Komunikasi}

Pemanfaatan new media untuk sarana promosi bagi perhotelan yang ada di kota Bengkulu ini, menggunakan media komunikasi jenis massa sangatlah diuntungkan, karena faktor utamanya adalah bisa menjangkau sasaran yang luas sehingga diinginkan dari para pelaku bisnis hotel-hotel yang ada di kota Bengkulu.

Terlebih lagi media partner sepertiOYO, RedDoorz dan Airy sudah berbasis jangkauan massa atau khalayak luas. Faktor inilah yang menjadikan para pelaku bisnis perhotelan di kota Bengkulu untuk memilih dan memanfaatkan media baru ini dalam mempromosikan hotel-hotel yang ada di kota Bengkulu.

Saluran komunikasi yang berbasis massa ini menjadi salah satu alasan kenapa para hotel-hotel di kota Bengkulu lebih memilih untuk memanfaatkan media baru dalam ajang bisnis hotel-hotel di kota Bengkulu dibandingkan dengan menggunakan metode konvensional secara interpersonal, yang sudah kurang efisien dalam menjangkau khalayak dan mencari konsumen di era yang saat ini sudah memasuki era digitalisasi.

\section{Pemanfaatan New Media Dari Model Difusi Inovasi: Sosial}

Sosial merupakan faktor penting dalam adanya inovasi, karena sosial yang menggerakan adanya perubahan yang bisa dirasakan saat ini. Sosial pun bisa berubah karena pola pikir yang sudah maju dan berpengetahuan, adanya kebutuhan dan kemauan yang berkembang dan berubah sehingga mempengaruhi orang lain untuk mengikuti perubahan yang terjadi.

Dalam persoalan yang terjadi di dalam penelitian ini, sosial menjadi seolah titik dimana dengan adanya sosial yang sudah mengalami perubahan sehingga bisa menimbulkan adanya inovasi didalamnya. Seperti halnya dalam penelitian pemanfaatan new mediadalam media promosi hotel-hotel di kota Bengkulu ini, mereka (pihak hotelhotel Bengkulu) melihat adanya faktor alasan kenapa memilih new media dalam promosi hotel-hotel di kota Bengkulu yang didasari adanya pengaruh sosial, adapun yaitu:

1. Sosial sudah berkembang dari masa konvensional ke arah modernitas, perubahan ini dikarenakan adanya teknologi dan revolusi digitalisasi yang ada saat ini, sehingga 
sosial yang ada di sekitar merasa bahwa dengan masuknya era baru yang digital, sehingga haruslah adanya perubahan didalamnya.

2. Kebutuhan dan keinginan dari sosial yang sudah meningkat dan berubah, sosial yang saat ini sudah mengenal gadget saat ini mengalami perubahan yang cukup signifikan, mulai dari kebutuhan yang saat ini harus sesuai dengan zaman (cepat, praktis dan mobile).

Adanya faktor-faktor yang disebutkan diatas menjadikan alasan bagi pihak hotel-hotel di kota Bengkulu dalam memanfaatkan media baru (new media) bahwa pengaruh yang ditimbulkan karena adanya perubahan zaman dan sosial menjadikan pihak hotel-hotel di kota Bengkulu memilih strategi promosi untuk memanfaatkan media baru.

Hotel-hotel yang bersangkutan tersebut melakukan kerja sama dengan pihak promoter dari media baru ini, merasa bahwa dengan menggunakan media baru (new media), dampak yang dirasakan bukan sekedar adanya stabilitas dari pemasukan mereka namun terlepas dari itu semua yang menjadi terpenting adalah media baru ini membantu dalam dunia persaingan antar hotel-hotel di kota Bengkulu yang saat ini sudah mulai ramai dan beragam. Serta menjadikan pilihan bagi para masyarakat yang saat ini sudah akrab dengan teknologi yang digunakan dalam kehidupan sehari-hari.

\section{SIMPULAN}

Inovasi merupakan hal yang sangat diperlukan dalam dunia bisnis, terkhususnya di bidang perhotelan yang seperti pada hotel-hotel di kota Bengkulu ini. Inovasi dimanfaatkan karena melihat adanya perkembangan zaman dan adanya kebutuhan yang berubah dari masyarakat (sosial) saat ini terjadi. Pemilihan media partner seperti OYO, RedDoorz dan Airy atau media baru lainnya menjadi pilihan yang tepat untuk dilakukan karena jangkauan yang luas dan beberapa kelebihan lainnya yang didapatkan dari media baru tersebut.

Pemilihan saluran komunikasi yang dilakukan pihak perhotelan yang ada di kota Bengkulu dengan menggunakan komunikasi massa sangat tepat dalam media promosi karena melihat jangkauannya yang luas dan bebas, menjadikan faktor tepat dalam memanfaatkan media baru saat ini.

Perhotelan di kota Bengkulu melihat bagaimana era sekarang yang sudah memasuki era digital dan arus bisnis saat ini yang mengharuskan para pelaku bisnis untuk menyesuaikan peluang. Maka dari itu setelah melihat ada dan banyaknya bisnis yang menggunakan media baru, maka keputusan dalam memilih partner dari media baru ini sangat tepat untuk dilakukan oleh perhotelan di kota Bengkulu

Pemanfaatan media baru saat ini sudah menjadi alternatif atau jalan yang digunakan oleh lingkungan sosial saat ini mulai untuk akses informasi, edukasi, hiburan hingga dipergunakan untuk bisnis. Pihak perhotelan di kota Bengkulu menjadikan alasan bahwa sekarang ini lingkungan sosial sudah menjadikan media baru sebagai media dalam mendapatkan informasi dan berbagai hal lainnya, maka dengan ikut serta juga dalam menggunakan media baru ini, para pihak perhotelan di kota Bengkulu 
memanfaatkan sosial saat ini yang sudah menggunakan media sebagai akses bagi lingkungan sosial.

\section{DAFTAR PUSTAKA}

Moleong, J, L. (2006). Metodologi Penelitian Kualitatif. Bandung: PT. Yudhistira Mulyana, D. (2005). Ilmu Komunikasi Suatu Pengantar. Bandung: Remaja RosdaKarya Suprapto, T. (2006). Pengantar Teori Komunikasi, Yogyakarta: Media Pressindo Flew, T. (2008). Media Baru : Sebuah Permulaan. Universitas Indonesia Press

Bataafi, W. (2005). House Keeping Departement, Floer and Publick Area, Bandung: Alfabeta 